ppi $201502 Z U 4645$

Esta publicación cientifica en formato digital es continuidad de la revista impresa ISSN-Versión Impresa 0798-1406 / ISSN-Versión on line 2542-3185Depósito legal pp

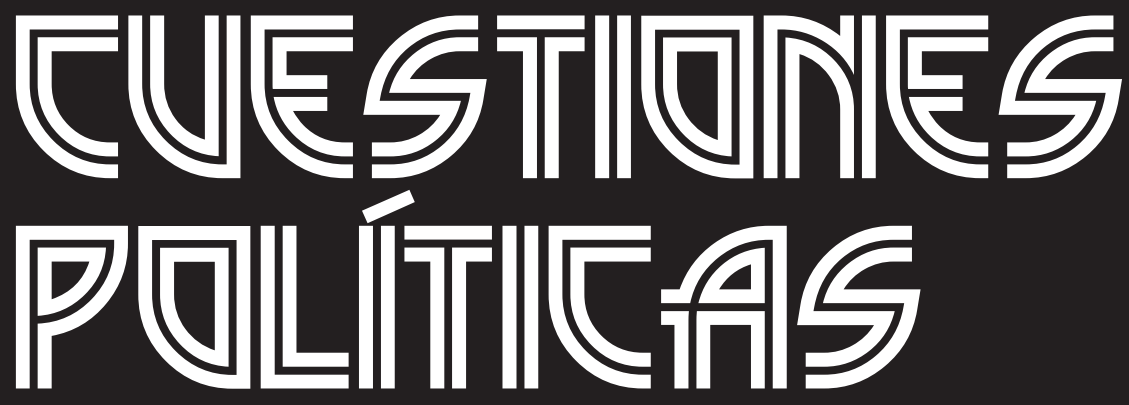

Instituto de Estudios Políticos y Derecho Público "Dr. Humberto J. La Roche' de la Facultad de Ciencias Jurídicas y Políticas de la Universidad del Zulia Maracaibo, Venezuela
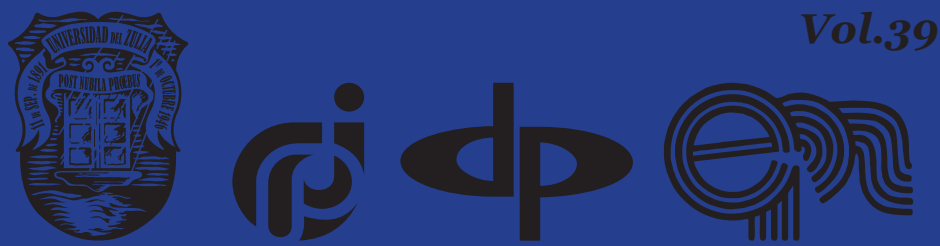


\title{
Criminal Liability for Organization of Illegal Migration
}

\author{
DOI: https://doi.org/10.46398/cuestpol.3968.37
}

\author{
Mariya Vyacheslavovna Talan * \\ Ildar Rustamovich Begishev ** \\ Tatyana Gennadievna Zhukova *** \\ Diana Davlenovna Bersei **** \\ Regina Rustemouna Musina **** \\ Bairamkulov Asker Magometovich ******
}

\section{Abstract}

The article discusses the criminal responsibility for illegally organizing migration, using a comparative documentary-based methodology. Constant changes in public life suggest the need to improve states' criminal policy in the field of establishing responsibility for organizing illegal migration, both nationally and internationally. An analysis of the provisions of international criminal law makes it possible to consider various legal approaches to the criminalization of acts in the field of migration. The document underpins the need to develop a unified approach to determining the characteristics of the crime in question, as it is transnational. It is concluded that, regardless of the different approaches of States to recognize illegal population migration, the organization of this illegal activity, in the presence of certain particular signs, should be recognized as a crime. At the same time, the organization of illegal migration is defined as the commission by a criminal group

* Professor in Law, Faculty of Law, Department of Criminal Law, Kazan Federal University, Kazan, Russia (Russian Federation). ORCID ID: https://orcid.org/oooo-0002-9852-5133. Email: kafedra. ksu@yandex.ru

** Ph. D. in Law, Senior Researcher, Kazan Innovative University named after V.G. Timiryasov, Kazan, Russia (Russian Federation). ORCID ID: https://orcid.org/oooo-ooo1-5619-4025. Email: begishev@ mail.ru

*** Ph. D. in Law, Faculty of Law, Department of Criminal Law and Procedure, North-Caucasus Federal University, Stavropol, Russia (Russian Federation), ORCID ID: https://orcid.org/oooo-0002-10118905. Email: tany_zhukova@mail.ru

**** Ph. D. in Law, Department of Criminal Law and Procedure, North-Caucasus Federal University, Stavropol, Russian Federation. ORCID ID: https://orcid.org/oooo-ooo1-7423-5978. Email: di.bersej2012@yandex.ru

***** Master of Law, Department of Criminal Law and Procedure, Kazan Innovative University named after V.G. Timiryasov, Kazan, Russia (Russian Federation). ORCID ID: https://orcid.org/oooo-0002-56704010. Email: unabhangig@yandex.ru

****** Ph. D. in Law, Department of Criminal Law Disciplines, North Caucasian State Academy, Cherkessk, Russia (Russian Federation). ORCID ID: https://orcid.org/oooo-0002-9493-1927. Email: Asker. magometovich@yandex.ru 
Mariya Vyacheslavovna Talan, Ildar Rustamovich Begishev, Tatyana Gennadievna Zhukova, Diana Davlenovna Bersei, Regina Rustemovna Musina y Bairamkulov Asker Magometovich

(association of criminal groups) of actions aimed at creating the conditions for the illegal movement of foreign nationals across the state border or their illegal presence in each country.

Keywords: Illegal migration; criminal organization; criminal liability; transnational crime; organization of illegal migration.

\section{Responsabilidad penal por organización de la migración ilegal}

\section{Resumen}

El artículo analiza la responsabilidad penal de organizar la migración de forma ilegal, mediante una metodología comparada de base documental. Los constantes cambios en la vida pública sugieren la necesidad de mejorar la política criminal de los estados en el campo de establecer la responsabilidad de organizar la migración ilegal, tanto a nivel nacional como internacional. Un análisis de las disposiciones del derecho penal internacional permite considerar diversos enfoques legales para la penalización de actos en el ámbito migratorio. El documento fundamenta la necesidad de desarrollar un enfoque unificado para determinar las características del delito en cuestión, ya que es transnacional. Se concluye que, independientemente de los diferentes enfoques de los Estados para reconocer la migración ilegal de la población, la organización de esta actividad ilegal, en presencia de ciertos signos particulares, debe ser reconocida como un delito. Al mismo tiempo, la organización de la migración ilegal se define como la comisión por parte de un grupo delictivo (asociación de grupos delictivos) de acciones encaminadas a crear las condiciones para el movimiento ilegal de ciudadanos extranjeros a través de la frontera estatal o su presencia ilegal en un país determinado.

Palabras clave: Migración ilegal; organización criminal; responsabilidad penal; crimen transnacional; organización de la migración ilegal.

\section{Introduction}

The relevance of the study of criminal law measures to combat illegal migration is predetermined by the fact that today one of the first threats to the national security of the state is the intensification of the activities of cross-border criminal groups organizing channels of illegal migration. This creates a danger for the normal development of states in the economic 
and social spheres of public life, infringes on public security. Criminal organizations illegally take socially unprotected people out of their countries with the aim of being involved in committing terrorist crimes, drug trafficking, arms trade, prostitution, etc. The approach to organizing illegal migration at the international level differs significantly from the understanding of this phenomenon in many countries of the world. An analysis of the provisions of the national criminal law systems showed that in most countries responsibility for organizing illegal migration is not associated with obtaining material benefits, a person should be held accountable if he pursued other goals of organizing illegal migration.

\section{Materials and methods}

When studying the illegal organization of migration, special attention should be paid to the historical analysis of the development trends of this legal institution, which makes it possible to reveal its essence, to identify the conditionality of the legal consolidation of the rules of behavior in accordance with the characteristics of the emerging social relations at a particular historical stage.

An analysis of the current state of legal prohibitions regarding the establishment of criminal liability for illegal organization of migration will make it possible to formulate a criminal-legal characteristic of the crime in question. A comparative legal study of legal regulation in the field of establishing responsibility for organizing illegal migration in different countries provides an opportunity to formulate a general global trend in the criminalization of acts in the field of illegal migration. Generalization of the experience of different countries is a necessary condition for finding the optimal model of criminal law regulation in terms of the research topic.

\section{Results and discussions}

Many studies show that the majority of "illegally migrating are enslaved" (Zhang, 2009). Yu. A. Kuzmenko claims, referring to the International Organization for Migration, that the organizers of illegal migration receive from 5 to 7 billion dollars a year (Kuzmenko, 2006). To effectively counter such criminal activity, it is necessary to analyze the legal signs of organizing illegal migration. "The integration of legal and economic activities in modern states, the globalization of various aspects of technology and human capital is the main characteristic of modern civilization" (Smirnov et al., 2018: 415).

Historical analysis of the development of criminal legislation in the field of legal regulation of migration allows us to assert that the consolidation of the prohibition on the commission of certain acts in the field of migration 
Mariya Vyacheslavovna Talan, Ildar Rustamovich Begishev, Tatyana Gennadievna Zhukova, Diana Davlenovna Bersei, Regina Rustemovna Musina y Bairamkulov Asker Magometovich

is directly related to the economic, social and political transformations in the country. One and the same act at different historical stages could be recognized as socially useful and socially dangerous. It seems that this specificity of the social relations under consideration distinguishes the illegal organization of migration from the majority of crimes, which at all times are recognized and recognized as socially dangerous (murder, theft, high treason, etc.).

Purposeful legal regulation of Russia's migration policy began in the 17th century. During this period, it was not limited, but rather encouraged the resettlement of foreigners and the development of new territories. This direction of the migration policy is reflected in the regulatory document, which can be considered one of the first acts regulating migration processes in the country. So, on April 27, 1702, Peter I signed the Manifesto "On the exportation of foreigners to Russia, promising them freedom of religion." "The reason for inviting foreigners is banal - the lack of people to carry out the colonization of the gigantic empty lands of the Russian Empire" (Kirov, 2001: 200).

By the end of the 18th and the beginning of the 19th century, the migration of foreigners to Russia stopped, which was a natural consequence of the Russian-Japanese war and the First World War.

During the reign of Nicholas II, a number of laws were issued, in accordance with which the eviction of migrants from the territory of Russia was organized (Pakhalyuk, 2013).

After the revolution that took place in Russia in 1917 and the establishment of Soviet power, the second of the previously identified stages in the development of criminal legislation in terms of establishing responsibility in the field of organizing population migration began.

Accordingly, the changes that have occurred in all spheres of society have led to a change in the understanding of the public danger of illegal resettlement of foreign citizens to the territory of the country, as a result of which such an act began to be recognized as socially dangerous and deserving severe punishment.

The Criminal Code of the Russian Federation (The Criminal Code of the Russian Federation of June 13, 1996 No. 63-FZ (hereinafter referred to as the Criminal Code of the Russian Federation) adopted in 1996, similar to the criminal legislation of the Soviet period, established responsibility for crossing the state border of the Russian Federation without established documents and appropriate permission (Art. 322 of the Criminal Code of the Russian Federation).

With the further development of legislation in the field of organizing migration processes, the number of acts that were recognized as criminal in this area also increased. 
At the beginning of the 21st century, Russian legislation in the field of organizing and controlling migration processes began to develop quite actively.

There have also been changes in Russian criminal legislation, primarily related to increased liability for illegal entry of foreign citizens into Russia. In 2004, Art. 322.1 "Organization of illegal migration of the Criminal Code of the Russian Federation (The Criminal Code of the Russian Federation, 1996).

The considered changes in the state policy in the field of migration are predetermined by the existing need to prevent negative consequences for the country from spontaneously and uncontrollably developing migration processes.

The public danger of the act under Art. 322.1 of the Criminal Code of the Russian Federation, is that when organizing illegal migration, the procedure for regulating migration processes established in the territory of the Russian Federation is violated, and also complicates the demographic situation in the country. Subsequently, these factors lead to the emergence of interethnic conflicts, undermine the economic and national security of the state. This creates additional obstacles in the fight against transnational crimes.

In accordance with the current Russian criminal law, the organization of illegal migration as a crime is a guilty socially dangerous act, expressed in the organization of illegal entry into the territory of the country of foreign citizens or stateless persons, their illegal stay in the country or organization of illegal transit through the territory of the state, specified persons.

Stricter responsibility for organizing illegal migration is provided for in Part 2 of Art. 322.1 of the Criminal Code of the Russian Federation, for organizing illegal migration by a group of persons by prior conspiracy, or by an organized group, as well as for the purpose of committing a crime on the territory of the Russian Federation, or the commission of a crime by a person using his official position. The maximum penalty in this case is imprisonment for a period of 7 years.

An analysis of judicial practice has shown that most mistakes in qualifying acts as organizing illegal migration are made due to the difficulties in delimiting the crime under Art. 322.1 of the Criminal Code of the Russian Federation from administrative offenses described in the Code of the Russian Federation on Administrative Offenses (Code of the Russian Federation on Administrative Offenses, 2001).

Part 3 of Art. 18.9 of the Code of Administrative Offenses of the Russian Federation establishes administrative responsibility for "the provision of housing or a vehicle or the provision of other services to a foreign citizen 
Mariya Vyacheslavovna Talan, Ildar Rustamovich Begishev, Tatyana Gennadievna Zhukova, Diana Davlenovna Bersei, Regina Rustemovna Musina y Bairamkulov Asker Magometovich

Criminal Liability for Organization of Illegal Migration

or stateless person who is in the Russian Federation in violation of the established procedure or rules for transit through its territory."

In this case, both an individual and a legal entity are held liable. For persons who committed the described offense using their official position, a penalty is provided in the form of a fine of up to 50,000 rubles, for other individuals - up to 5,000 rubles. Legal entities for committing these actions are punished with a fine of up to 400,000 rubles.

In Art. 18.15 of the Code of Administrative Offenses of the Russian Federation is recognized as an administrative offense "involving a foreign citizen or stateless person in labor activity in the Russian Federation in the absence of a work permit", which entails the imposition of an administrative penalty. For individuals, the punishment is similar to that indicated above, and legal entities are punished more severely - with a fine of up to 800 thousand rubles or suspension of activities for up to 90 days (Code of the Russian Federation on Administrative Offenses, 2001

These actions can also be considered as a manifestation of the organization of illegal stay on the territory of Russia of foreign citizens.

It seems that in this case the delimitation of actions constituting an administrative offense from a criminal offense should be carried out in accordance with the establishment of the fact that it is legal or illegal to be in the territory of Russia a migrant. In the first case, there is a basis for criminal liability, and in the second, administrative.

In the countries of the so-called post-Soviet space, the approach to establishing criminal liability for organizing illegal migration is similar to the provisions of Russian legislation.

In the criminal laws of Azerbaijan, Georgia, Uzbekistan, Turkmenistan, Kyrgyzstan, there is no norm providing for criminal liability for organizing illegal migration. At the same time, unlike Russia, they establish criminal liability for illegal movement across the state border if this act is committed in the presence of aggravating circumstances, for example, committed with the use of violence (with the threat of its use) or committed by an organized group (Skhimnikova, 2015).

For example, for the aforementioned actions under the Criminal Code of Uzbekistan for illegal travel abroad or illegal entry into the Republic of Uzbekistan, a penalty of imprisonment for a period of three to five years is established (Article 223) (The Criminal Code of the Republic of Uzbekistan, 1994).

Interesting, at the same time, is the legislator's approach to differentiating criminal liability for illegal movement across the border, taking into account the identity of the perpetrator. So, in accordance with the Criminal Code of Uzbekistan, punishment in the form of imprisonment for up to 10 years 
is established for moving across the border of the Republic of Uzbekistan in violation of the established procedure, if this act was committed by a dangerous repeat offender or an official whose travel abroad, without special permission, is prohibited (The Criminal Code of the Republic of Uzbekistan, 1994)

Spain became one of the first European states to face the fact that the unauthorized migration of foreigners on its territory gives rise to a number of social and economic problems, including an increase in crime and the use of migrant labor without state control. Consequently Skhimnikova (2015):

\begin{abstract}
Spanish legislation has detailed issues related to creating conditions for combating illegal migration, especially with organized forms of crime in the migration sphere. In accordance with the "Law on Foreigners" in Spain, criminal punishment is provided for such actions as facilitating the creation or participation in criminal organizations involved in the delivery of illegal immigrants to the country or using its territory as a transit (Article 50) (2015: 101).
\end{abstract}

Compared to Russian criminal law, illegal migration is punished quite strictly in Bulgaria. In accordance with the Criminal Code of Bulgaria, a person who crosses the border of the country without the permission of the relevant state organizations should be punished with imprisonment for up to five years (Article 279) (Lukashov, 2001). As an aggravating circumstance, responsibility for the indicated crime is provided for the commission of such an act a second time, for which responsibility is imposed in the form of deprivation of freedom for up to six years.

The Criminal Code of Bulgaria established responsibility for preparing illegal movement across the state border, which is punishable by imprisonment for up to two years (Skhimnikova, 2015).

The liability of persons organizing the unauthorized crossing of the state border of Bulgaria by other persons is provided separately in Art. 280 of the Criminal Code of Bulgaria (Lukashov, 2001).

Of greatest interest are the circumstances established in the Criminal Code of Bulgaria that aggravate the responsibility for organizing illegal migration.

Up to 10 years of imprisonment is punishable by organizing the movement of a person across the state border if the person being displaced: has not reached 16 years of age; is not a Bulgarian citizen; did not know that he was being illegally transported across the border (Lukashov, 2001).

Indeed, these circumstances significantly increase the degree of public danger of organizing illegal migration, primarily due to the fact that they infringe not only on the management order, but also on the interests, personal rights and freedoms of the displaced person. 
Mariya Vyacheslavovna Talan, Ildar Rustamovich Begishev, Tatyana Gennadievna Zhukova, Diana Davlenovna Bersei, Regina Rustemovna Musina y Bairamkulov Asker Magometovich

As a circumstance aggravating responsibility for organizing illegal migration, in Bulgaria it is indicated that such an act was committed using mechanical, air or other transport. Special confiscation is provided for by Part 3 of Art. 280 of the Criminal Code of Bulgaria, which stipulates that in these cases, the transport, if it belongs to the culprit, is recovered by the state (Lukashov, 2001).

Criminal liability is also increased if the transportation was organized by groups of persons or the grouping of groups or the transportation was carried out with the participation of an official who used his official position.

In the Criminal Code of the Federal Republic of Germany in section 18 "Punished acts against personal freedom", in paragraph 234 "Forcible removal of people abroad" criminal liability is established for moving a person across the border of Germany, against his will. In addition, the preparation of such a transfer is in itself recognized as a punishable act. Paragraph 235 of the Criminal Code of the Federal Republic of Germany, as a more severe act, provides for the commission of these actions in relation to a minor (Shestakov, 2003).

In the Criminal Code of the PRC, the system of criminal-legal prohibitions in the field of organizing illegal migration includes legal prohibitions that criminalize various manifestations of unauthorized migration of the population and are aimed at preventing its organization. In accordance with Art. 318 of the Criminal Code of the PRC, the organization of illegal migration can be punished not only by imprisonment for a certain period, but also by life imprisonment (Korobeyev, 2001).

However, criminal liability under this provision does not arise in all cases of illegal organization of migration, but only if:

- the person is the leader of the group organizing the illegal crossing of the state border.

- the organization of illegal migration was carried out repeatedly.

- as a result of illegal migration, harm to life or health was caused to persons whose migration was organized.

- migration was carried out with the use of threats and violence.

- the presence of other aggravating circumstances, serious violations in the implementation of migration organized by a person (Korobeyev, 2001).

According to, Hanson (2007): "Immigration reform is one of the most controversial issues facing US policymakers" (2007: 12). The growth in the number of illegal immigrants in the United States is of great concern, therefore, the country pays great attention to suppressing the organization 
of illegal migration, including by eliminating its primary cause, which is seen in the possibility of using migrant labor by American corporations.

The tougher punishment for illegal migration is associated with the events of 2001, namely with the terrorist attack on the World Trade Center (Singer and Golan, 2019), one of the reasons for not preventing which the US government saw in uncontrolled migration.

The study showed that of 94 foreign terrorists who operated in the United States, about two thirds crossed the border illegally (Kephart, 2006). Fillipenko says:

In October 2001, a Mexican citizen of Iraqi descent confessed to smuggling hundreds of Syrians, Iraqis, Palestinians, Jordanians, and other citizens of Arab countries into the United States, each of whom paid from 10 to 15 thousand dollars to move from their homeland to the United States. and most of this money went to the "coyotes" - mafia organizations that specialize in smuggling illegal goods and undocumented persons from Mexico (2015:180).

In the United States, the following categories of persons are distinguished as subjects of crimes in the field of illegal migration:

- employers who illegally use migrant labor.

- the migrants themselves who are in the United States illegally.

- persons organizing illegal migration.

The importation of any foreigner into the United States for the purpose of prostitution or any other immoral purpose is prohibited (The Immigration and Citizenship Act (INA)) was passed in 1952. The text contains those laws that entered into force on May 20, 2020. For persons who organize the illegal entry of foreign nationals into the United States for these purposes or his stay in the United States, under Title 18, a penalty of a fine(s) or imprisonment for up to 10 years is provided. At the same time, even a failed attempt to commit the described act is recognized as a criminal offense.

If these actions are associated with the infliction of grievous bodily damages or with the threat of their commission, then for the organization of illegal migration a term of imprisonment of up to 20 years is provided. In the event of a person's death, life imprisonment may be imposed.

It seems reasonable that the repeated or systematic commission of the described acts is provided as a circumstance aggravating criminal liability for helping a foreigner to illegally enter the United States or stay in the United States.

The number of migrants against whom a crime is committed also affects the severity of the punishment (Bokovnya et al., 2019; Begishev et al., 2020; Begishev et al., 2019; Bokovnya et al., 2020; Begishev et al., 2019; Bokovnya et al., 2020; Bokovnya et al., 2020; Bokovnya et al., 2020; Khisamova et 
Mariya Vyacheslavovna Talan, Ildar Rustamovich Begishev, Tatyana Gennadievna Zhukova, Diana Davlenovna Bersei, Regina Rustemovna Musina y Bairamkulov Asker Magometovich

al., 2019; Bokovnya et al., 2020; Begishev and Khisamova, 2018; Begishev et al., 2020; Khisamova and Begishev, 2019; Khisamova et al., 2019).

Thus, illegal transportation of foreigners by groups of more than 10 people is punishable by imprisonment for up to 10 years, while for committing similar actions against a smaller number of people, imprisonment cannot be imposed for more than 5 years (US Immigration and Citizenship).

\section{Summary}

Summing up the study of the provisions of the criminal law of different countries of the world, in terms of countering illegal migration, it should be noted that in those countries in which such responsibility is provided, in most cases the legislator differentiates responsibility for organizing illegal migration.

Organization of migration is an activity that involves the involvement of many persons acting by prior agreement (officials of regulatory bodies, carriers, security guards, etc.)

It seems that the activities of these persons should be considered with their participation in the organization of illegal migration as co-execution in the commission of the crime in question.

Responsibility for organizing illegal migration should be stricter in cases: organizing illegal migration for the purpose of committing serious crimes (terrorism, slave trade, involvement in prostitution, drug trafficking, etc.) and in cases when it is associated with causing serious harm to health or death of a person.

In many countries, stricter criminal liability is established by specifying circumstances related to the characteristics of the identity of the perpetrator or person illegally transferred across the state border.

Many issues related to illegal migration have long gone beyond the boundaries of any territories and can rightfully be considered global, which means that their solution is possible only with the interaction of all countries of the world.

For example, as the International Organization for Migration emphasizes, "during the COVID-19 pandemic, the vulnerability of migrant workers increased significantly, as many of them found themselves in an irregular situation, expired their work visas, could not pay off debts accumulated through recruiting or supporting families at home" (IOM, Migrant Forum in Asia Partner to Promote the Rights of Migrant Workers in International Supply Chains, 2020). And this problem has affected all countries today. 
According to Art. 3 of the Protocol against the Smuggling of Migrants by Land, Sea and Air, supplementing the UN Convention against Transnational Organized Crime (United Nations Convention against Transnational Organized Crime, the organization of illegal migration should be understood as "the smuggling of migrants in order to obtain, directly or indirectly, any financial or other material benefit from illegal entry to any State of any person who is not its citizen or does not reside permanently on its territory" (Protocol against the Smuggling of Migrants by Land, Sea and Air Supplementary to the United Nations Convention against Transnational Organized Crime, 2000)

Thus, the approach to organizing illegal migration at the international level differs significantly from the understanding of this phenomenon in many countries of the world. An analysis of the provisions of the national criminal law systems showed that in most countries responsibility for organizing illegal migration is not associated with obtaining material benefits, a person should be held accountable if he pursued other goals of organizing illegal migration.

\section{Conclusions}

I would like to draw attention to the need for a more thorough international regulation of migration processes. Violations in this area are undeniably transnational in nature. Many global problems of our time are associated with illegal migration require joint efforts of states in their solution.

A distinction should be made between offenses and crimes in the field of migration. If the issues of administrative and legal regulation of migration processes in each country depend on the peculiarities of the social system that has developed in this state and predetermined by the historical features of development, then the composition of offenses expressed in violation of the migration regime will be quite diverse. At the same time, most countries take a similar position in the establishment of criminal responsibility for organizing illegal migration.

\section{Acknowledgements}

The work is performed according to the Russian Government Program of Competitive Growth of Kazan Federal University. 
Mariya Vyacheslavovna Talan, Ildar Rustamovich Begishev, Tatyana Gennadievna Zhukova, Diana Davlenovna Bersei, Regina Rustemovna Musina y Bairamkulov Asker Magometovich

\section{Bibliographic References}

BEGISHEV, Ildar R; KHISAMOVA, Zarina I. 2018. "Criminological Risks of Using Artificial Intelligence” In: Vserossiiskii kriminologicheskii zhurnal $=$ Russian Journal of Criminology. Vol. 12, No. 6, pp. 767-775.

BEGISHEV, Ildar R; KHISAMOVA, Zarina I; MAZITOVA, Guzel I. 2019. "Information Infrastructure of Safe Computer Attack" In: Helix. Vol. 9, No. 5 , pp. 5639-5642.

BEGISHEV, Ildar R; KHISAMOVA, Zarina I; NIKITIN, Sergio. 2020. “The Organization of Hacking Community: Criminological and Criminal Law Aspects" In: Vserossiiskii kriminologicheskii zhurnal = Russian Journal of Criminology. Vol. 14, No. 1, pp. 96-105.

BEGISHEV,Ildar R; KHISAMOVA,Zarina;MAZITOVA, GuzelI.2019. “Criminal Legal Ensuring of Security of Critical Information Infrastructure of the Russian Federation" In: Revista Gênero \& Direito. Vol. 8, No. 6, pp. 283292.

BEGISHEV, Ildar R; LATYPOVA, ElviraYu; KIRPICHNIKOV, Danila V. 2020. "Artificial Intelligence as a Legal Category: Doctrinal Approach to Formulating a Definition" In: Actual Problems of Economics and Law. Vol. 14, No. 1, pp. 79-91.

BOKOVNYA, Alexandra Yu; BEGISHEV, Ildar R; KHISAMOVA, Zarina I; BIKEEV, Indesa.I; SIDORENKO, Elina L; BERSEI, Delana D. 2020. "Pressing Issues of Unlawful Application of Artificial Intelligence" In: International Journal of Criminology and Sociology. Vol. 9, pp. 10541057 .

BOKOVNYA, Alexandra Yu; BEGISHEV, Ildar; KHISAMOVA, Zarina I; NARIMANOVA, Nelli Rashidovna; SHERBAKOVA, Lyudmila Mikhailovna; MININA, Alexandra. 2020. "Legal Approaches to Artificial Intelligence Concept and Essence Definition” In: Revista San Gregorio. Vol. 41, pp. 115-121.

BOKOVNYA, Alexandra Yu; KHISAMOVA, Zarina I; BEGISHEV, Ildar R; LATYPOVA, ElviraYu; NECHAEVA, Evgeniya V. 2020. "Computer Crimes on the COVID-19 Scene: Analysis of Social, Legal, and Criminal Threats” In: Cuestiones Políticas. Vol. 38, No. 66, pp. 463-472.

BOKOVNYA, Alexandra Yu; KHISAMOVA, Zarina I; BEGISHEV, Ildar R; SIDORENKO, Elina. L; ILYASHENKO, Alexander. N; MOROZOV, Andre Yu. 2020. "Global Analysis of Accountability for Fake News Spread about the COVID-19 Pandemic in Social Media" In: Applied Linguistics Research Journal. Vol. 4, No. 7, pp. 91-95. 
BOKOVNYA, Alexandra Yu; KHISAMOVA, Zarina I; VASYUKOV, V.F; BEGISHEV, Ildar R. 2020. "Assessment of Potential Risks of Regional for Global Financial Security" In: Cuestiones Políticas. Vol 38, No. 66, pp. 156-166.

BOKOVNYA, Alexandra Yu; KHISAMOVA, Zarina; BEGISHEV, Ildar R. 2019. "Study of Russia and the UK legislations in combating digital crimes" In: Helix. Vol. 9, No. 5, pp. 5458-5461.

CODE OF THE RUSSIAN FEDERATION ON ADMINISTRATIVE OFFENSES No. 195-FZ. 2001. (as amended on April 24, 2020). Hereinafter - the Code of Administrative Offenses of the Russian Federation. Available online. In: www.pravo.gov.ru. Consultation date: 05/01/2020.

FILLIPENKO, Alexandra Alexandrovna. 2015. Problems of US immigration policy in the period 1990-2015: Dissertation of the candidate of legal sciences. - M., - $180 \mathrm{p}$.

HANSON, Gordon Howard. 2007. The economic logic of illegal immigration. Council on Foreign Relations. New York, USA.

KEPHART, Janice L. 2006. "Immigration and Terrorism Moving Beyond the 9/11 Staff Report on Terrorist Travel” In: Connections: The Quarterly Journal. Vol. 5, No. 2, pp. 55-97.

KHISAMOVA, Z. I; BEGISHEV, I. R. 2019. "Criminal Liability and Artificial Intelligence: Theoretical and Applied Aspects" In: Vserossiiskii kriminologicheskii zhurnal = Russian Journal of Criminology. Vol. 13, No. 4, pp. 564-574.

KHISAMOVA, Zarina; BEGISHEV, Ildar R; GAIFUTDINOV, Ramil R. 2019. "On Methods to Legal Regulation of Artificial Intelligence in the World" In: International Journal of Innovative Technology and Exploring Engineering. Vol. 9, No. 1, pp. 5159-5162.

KHISAMOVA, Zarina; BEGISHEV, Ildar R; SIDORENKO, Elina L. 2019. "Artificial Intelligence and Problems of Ensuring Cyber Security" In: International Journal of Cyber Criminology. Vol. 13, No. 2, pp. 564-577.

KIROV, Andre. 2001. Legislation on the allocation of territories for foreign colonists in the Volga region and Central Russia during the reign of Catherine. Yekaterinburg, Russia. Pp. 194-210.

KOROBEYEV, Alexandr. 2001. Criminal Code of the People's Republic of China. - SPb .: Publishing house "Legal Center Press". Beijing, China.

KUZMENKO, Yuldir. 2006. Illegal labor migration as an object of criminological study: Dissertation of the candidate of legal sciences. Rostov, Russia. 
Mariya Vyacheslavovna Talan, Ildar Rustamovich Begishev, Tatyana Gennadievna Zhukova, Diana Davlenovna Bersei, Regina Rustemovna Musina y Bairamkulov Asker Magometovich

LUKASHOV, Alexi. 2001. The Criminal Code of the Republic of Bulgaria. SPb. Publishing house "Legal Center Press". Sofia, Bulgaria.

PAKHALYUK, Konstantin A. 2013. Great and forgotten. Materials of the scientific conference. November 10-11, 2012. Kaliningrad-Gusev, Russia.

SHESTAKOV, Dmitry A. 2003. Criminal Code of the Federal Republic of Germany. - SPb: Publishing house "Legal Center Press". Berlin, Germany.

SINGER, Gonen; GOLAN, Maya. 2019. "Identification of subgroups of terror attacks with shared characteristics for the purpose of preventing masscasualty attacks: a data-mining approach" In: Crime Science. Vol. 8, No. 14, pp. 74-86.

SKHIMNIKOVA, Ksenia Mikhailovna. 2015. "Responsibility for organizing illegal migration in foreign countries" In: Eurasian Law Journal. Vol. 5, No. 84, pp. 100-103.

SMIRNOV, Dmitry Anatolievich; STRUS, Konstantin Aleksandrovich; AVANESOVA, Anna Artemovna. 2018. "Features of the taxation in the territories with the special mode of business and investing activities: comparative analysis of the Russian and foreign best practices" In: International Journal of Engineering \& Technology. Vol. 7, No. 3 (14), pp. 412-420.

THE CRIMINAL CODE OF THE RUSSIAN FEDERATION. 1996. The Criminal Code of the Russian Federation of June 13, No. 63-FZ.Art. 322. Available online. In: www.pravo.gov.ru. Consultation date: 05/01/2020.

THE IMMIGRATION AND CITIZENSHIP ACT (INA). 1952. The text contains those laws that entered into force on May 20, 2020. Available online. In: https://www.uscis.gov/legal-resources/immigration-and-nationalityact. Consultation date: 25/05/2020.

US IMMIGRATION AND CITIZENSHIP ACT. 1997. Available online. In: https://www.uscis.gov/legal-resources/immigration-and-nationalityact. Consultation date: 05/01/2020.

ZHANG, Sheldon X. 2009. Looking for a Hidden Population: Trafficking of Migrant Laborers in San Diego County. United States Department of Justice. Office of Justice Programs. National Institute of Justice. Available online. In: https://www.ncjrs.gov/pdffiles1/nij/grants/240223.pdf. Consultation date: $05 / 01 / 2020$.

THE CRIMINAL CODE OF THE REPUBLIC OF UZBEKISTAN .1994. Approved by the Law of the Republic of Uzbekistan dated September 22, No. 2012-XII. As amended on March 26, 2020. Available online. In: 
https://online.zakon.kz/document/?doc_id=30421110). Consultation date: $05 / 01 / 2020$.

IOM. MIGRANT FORUM IN ASIA PARTNER TO PROMOTE THE RIGHTS OF MIGRANT WORKERS IN INTERNATIONAL SUPPLY CHAINS. 2020. Available online. In: https://www.iom.int/news/iom-migrantforum-asia-partner-promote-rights-migrant-workers-internationalsupply-chains. Consultation date: 05/01/2020.

PROTOCOLAGAINSTTHESMUGGLINGOFMIGRANTS BYLAND, SEAAND AIR SUPPLEMENTARY TO THE UNITED NATIONS CONVENTION AGAINST TRANSNATIONAL ORGANIZED CRIME. 2000. Resolution $55 / 25$ at the $62 n d$ plenary meeting of the $55^{\text {th }}$ session of the UN General Assembly. Bulletin of international treaties. 2005. No. 2. P. 34-46. Available online. In: https://www.un.org/ru/documents/decl_conv/ conventions/orgcrime.shtml. Consultation date: 05/01/2020. 

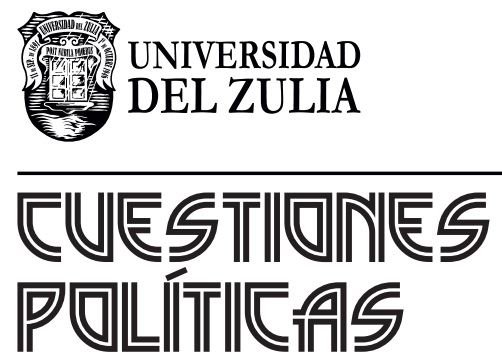

Vol.39 No 68

Esta revista fue editada en formato digital y publicada en enero de 2021, por el Fondo Editorial Serbiluz, Universidad del Zulia. Maracaibo-Venezuela 